\title{
PETROCHEMICAL CLASSIFICATION OF KIMBERLITES FROM YAKURIAN PROVINCE
}

\author{
S.I. Kostrovitsky \\ Institute of Geochemistry, Siberian Branch RAS, 1A Favorsky Str., Irkutsk, 664033 Russia \\ serkost@igc.irk.ru
}

Kimberlites of Yakutian province are known to be characterized by wide variations in rockforming oxides $[1-3,6]$. There are some factors that are responsible for the diversity of chemical compositions of rocks. One of the factors can be conventionally called primary-magmatic. It implies that the regional differences in the composition of kimberlites recorded either throughout the Yakutian Province or within its separate fields stem from the originally different compositions of the initial kimberlite fluxed melts. The other factors are related to the secondary redistribution of chemical components of kimberlites. It seems reasonable to distinguish a certain petrochemical type only if it reflects the specific primary composition of the kimberlite. Seemingly, the abundance of secondary factors of redistribution of petrochemical oxides should completely mutilate the primary composition of kimberlites and, hence, there is no sense in distinguishing any petrochemical types. However, this is not the case. Such oxides as $\mathrm{TiO}_{2}, \mathrm{FeOtot}$, $\mathrm{K}_{2} \mathrm{O}, \mathrm{Al}_{2} \mathrm{O}_{3}$, and $\mathrm{P}_{2} \mathrm{O}_{5}$ are relatively inert in secondary processes $[2,5]$. Within each kimberlite field in both southern and northern parts of Yakutian Province, there are pipes and even clusters of pipes filled by kimberlites with relatively high or low contents of $\mathrm{TiO}_{2}$, FeOtot, and $\mathrm{K}_{2} \mathrm{O}$.

The summarized literature and our own data concerning the chemical composition of kimberlites suggest that the kimberlites developed within the Yakutian province can be divided into several petrochemical types, whose origin is related to different mantle sources. The petrochemical classification of kimberlites is based on persistent differences of their composition in contents of indicator oxides such as $\mathrm{FeO}_{\text {total }}, \mathrm{TiO}_{2}$, and $\mathrm{K}_{2} \mathrm{O}$. According to chemical composition, the following contrasting types of kimberlites (Tabl. 1) have been recognized within the Yakutian Province.

The contents of $\mathrm{TiO}_{2}$ and $\mathrm{FeO}_{\text {total }}$ in the $1^{\text {st }}$ type of kimberlites vary in a narrow range, within the fluctuations typical of this type of rocks. For instance, the contents of $\mathrm{TiO}_{2}$ in the kimberlites of the Internatsional'naya and Aikhal pipes vary from 0.2 to 1.26 and from 0.1 to $0.96 \mathrm{wt} . \%$ as estimated from 163 and 313 analyses, respectively.
Table 1. Petrochemical types of kimberlites distinguished within the Yakutian Province.

\begin{tabular}{|l|l|l|l|l|}
\hline \multicolumn{2}{|c|}{ Petrochemical type } & \multicolumn{3}{c|}{$\begin{array}{l}\text { Content of indicator } \\
\text { oxides (wt. \%) }\end{array}$} \\
\hline № & Description & FeOt & TiO2 & K2O \\
\hline 1 & $\begin{array}{l}\text { High-Mg, low-Ti, } \\
\text { low-K }\end{array}$ & $<6$ & $<1$ & $<1$ \\
\hline 2 & $\begin{array}{l}\text { High-Mg, low-Ti, } \\
\text { high-K }\end{array}$ & $<6$ & $<1$ & $1-2,5$ \\
\hline 3 & $\begin{array}{l}\text { Mg-Fe, high-Ti, } \\
\text { low-K }\end{array}$ & $6-9$ & $1-2,5$ & $<1$ \\
\hline 4 & Fe-Ti, low-K & $9-15$ & $1,5-7$ & $<2,0$ \\
\hline 5 & Fe-Ti, high-K & $9-15$ & $1,5-7$ & $2,0-5$ \\
\hline
\end{tabular}

\begin{tabular}{|l|l|l|}
\hline № & $\begin{array}{l}\text { Pipes from Yakutian Province } \\
\text { (examples) }\end{array}$ & \multicolumn{1}{|c|}{$\begin{array}{c}\text { Area of } \\
\text { occurrence }\end{array}$} \\
\hline 1 & $\begin{array}{l}\text { Aikhal, } \\
\text { Internatsional'naya, } \\
\text { Obnazhennaya }\end{array}$ & $\begin{array}{l}\text { All } \\
\text { diamondiferous } \\
\text { fields but Nakyn }\end{array}$ \\
\hline 2 & $\begin{array}{l}\text { Dachnaya, Zagadochnaya, } \\
\text { Bukovinskaya, Nurbinskaya }\end{array}$ & $\begin{array}{l}\text { Malaya Botuobia } \\
\text { Daldyn, } \\
\text { and Nakyn field }\end{array}$ \\
\hline 3 & $\begin{array}{l}\text { Mir, Udachnaya, Dal'nyaya, } \\
\text { Zarnitsa, Sytykan, } \\
\text { Yubileinaya, Zapolyarnaya }\end{array}$ & $\begin{array}{l}\text { All } \\
\text { diamondiferous } \\
\text { fields but Nakyn }\end{array}$ \\
\hline 4 & $\begin{array}{l}\text { Druzhba (Chomurdah field), } \\
\text { Kosmicheskaya (Ary-Mastakh } \\
\text { field) } \\
\text { Victoriya (Staraya Rechka field) }\end{array}$ & Northern fields \\
\hline 5 & $\begin{array}{l}\text { Luchakan, Pozdnyaya (Luchaka } \\
\text { field), Rudny dvor, Bargydymal } \\
\text { (Ary-Mastakh field) }\end{array}$ & \\
\hline
\end{tabular}

The Mg-Fe kimberlites (Mir and Udachnaya pipes) are characterized by a wide range of contents of these oxides $\left(0.1-2.5\right.$ wt. $\% \mathrm{TiO}_{2}$ and $3-15 \%$ FeOtot, respectively), which suggests an ability of this type to differentiation.

The expediency of recognition of petrochemical types is confirmed by the study of the composition characteristics of rock-forming and accessory minerals. For example, the $\mathrm{Mg}-\mathrm{Fe}$ type of kimberlite usually contains olivine with a widely varying composition (from 7 to $14 \%$ fayalite end-member), picroilmenite being predominant in the heavy fraction. The high-Mg kimberlites contain olivine with usually no more than $8-9 \%$ fayalite, the heavy fraction being dominated by 
garnet and Cr-spinel and being almost free of minerals of low-Cr megacryst association (e.g., in the Aikhal and Internatsional'naya pipes). The Fe-Ti type of kimberlite demonstrates distinct differences in terms of the mineral composition in the matrix.

We have studied the spatial distribution of kimberlite petrochemical types within different fields of the Yakutian province. The Nakyn field contains only high-Mg type of kimberlites; the Malaya Botuobiya field shows high-Mg and $\mathrm{Mg}-\mathrm{Fe}$ types almost in equal proportions; the Daldyn, Alakit-Markha and Upper Muna fields are dominated by $\mathrm{Mg}-\mathrm{Fe}$ type of kimberlite, while in the north of the Yakutian province the Fe-Ti type is predominant.

The most important feature of distribution of isotopic and trace-element (incompatible elements) compositions [4] is their independence of the chemical rock composition (Fig. 1, 2). Different petrochemical types demonstrate similar contents of incoherent elements as well as the one and the same distribution pattern on spider diagrams. It is shown that the kimberlite formation is connected with, at least, two independent sources, fluid and melt, responsible for the trace-element (in terms of incoherent elements) and chemical compositions of the rock. It is supposed that, when rising through the heterogeneous lithosphere of the mantle, a powerful flow of an asthenospherederived fluid provoked the formation of local kimberlite chambers there. The different composition of the lithosphere mantle led to the formation of contrasting petrochemical types of kimberlites, while the geochemical specialization of kimberlites is due to the mantle fluid of asthenosphere origin, which drastically dominated in the rare-metal balance of hybrid magma of the chamber.

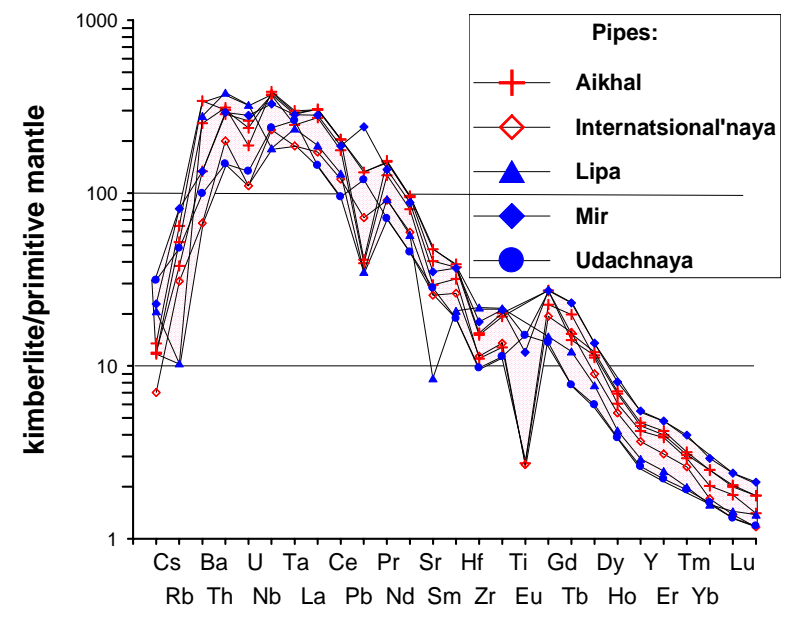

Fig. 1. Spidergrams of distribution of primitive-mantlenormalized trace elements (McDonough and Sun, 1995). For kimberlites of petrochemical types 1 (Aikhal and Internatsional'naya pipes) and 3 (lipa, Mir, Udachnaya pipes). For kimberlites of petrochemical types 4 (Anomaly 84, Pozdnyaya) and 5

(Otricatelnaya, Lihchan, Dama pipes).
Petrochemical composition of kimberlites is regarded as a result of the partial melting of the rocks of the lithosphere mantle and as a simple capture of disintegrated lithospheric substance by the astenospheric fluid. The ratio of these two mechanisms for forming petrochemical composition was in our viewpoint different for different kimberlite pipes. Kimberlites from diamond-bearing fields, mainly originate during disintegration of lithosperic mantle, while the partial melting of the lithospheric mantle was significant for kimberlites from the northern diamondfree fields.

The generalized data indicate that other provinces of the world (South African Republic, Lesotho, USA, China, Finland) are dominated by $\mathrm{Mg}-\mathrm{Fe}$ petrochemical type of kimberlites. Canada (Slave Province, Ekati, Las de Grass fields) is dominated by high-Mg type.

The study was supported by grant 06-05-64981 from the Russian Foundation for Basic Research and by collaborative projects of the Siberian Branch of the RAS (no. 21) and Department of Geosciences of the RAS (no. 7.2.1).

\section{References}

1. Ilupin, I.P., Kaminsky, F.V., Frantsesson, E.V., 1978. Geochemistry of kimberlites [in Russian]. Nedra, Moscow. 2. Khar'kiv, A.D., Zuenko, V.V., Zinchuk, N.N., Kryuchkov, A.I., Ukhanov, V.A., Bogatykh, M.M., 1991. Petrochemistry of kimberlites [in Russian]. Nedra, Moscow.

3. Kostrovitsky, S.I., 1986. Geochemical features of minerals from kimberlites [in Russian]. Nauka, Novosibirsk.

4. Kostrovitsky, S.I., Morikiyo, T., Serov, I.V., Rotman, A.Ya., 2004. Origin of kimberlites: evidence from isotopicgeochemical data. Dokl. Earth Sci. 399, 1164-1168.

5. Milashev, V.A., 1965. Petrochemistry of Yakutian kimberlites and factors of

their diamond potential [in Russian]. Nedra, Leningrad.

6. Nikishov, K.N., 1984. Petrologo-mineralogical model of kimberlite process [in Russian]. Nauka, Moscow.

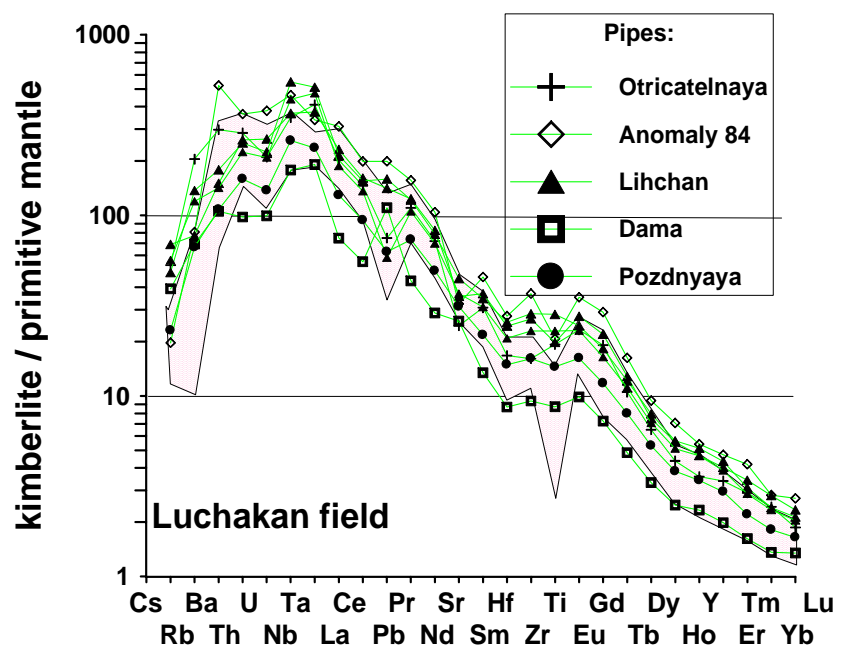



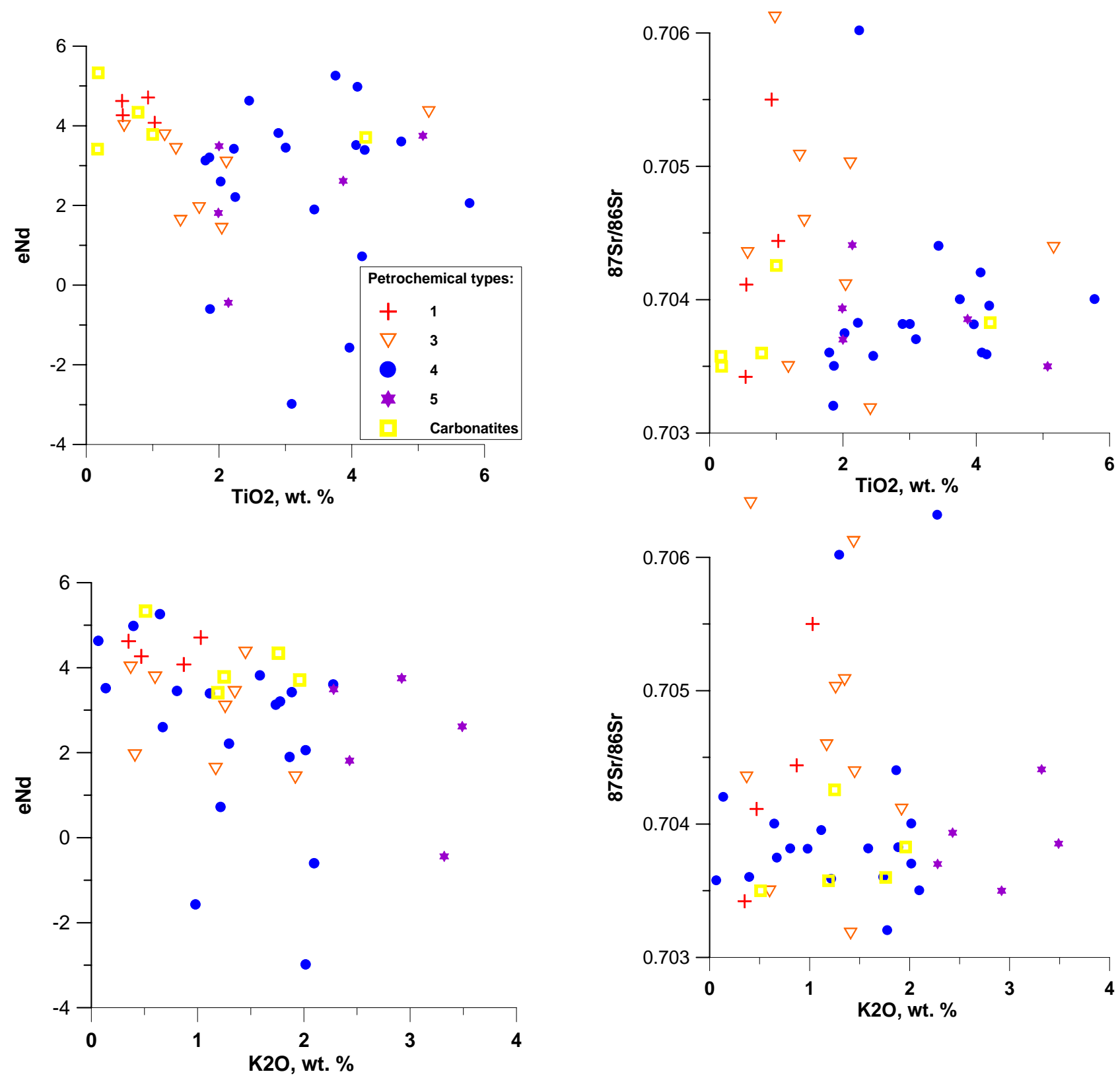

Fig. 2. Isotopic compositions of $\mathrm{Sr}$ and $\mathrm{Nd}$ as a function of $\mathrm{TiO} 2$ and $\mathrm{K} 2 \mathrm{O}$ in kimberlites and related rocks of the Yakutian province. On the Legend petrochemical types of kimberlites. Carbonatites form pipes in the within the bounds of kimberlite fields on the north of Yakutian province (Anabar region). 